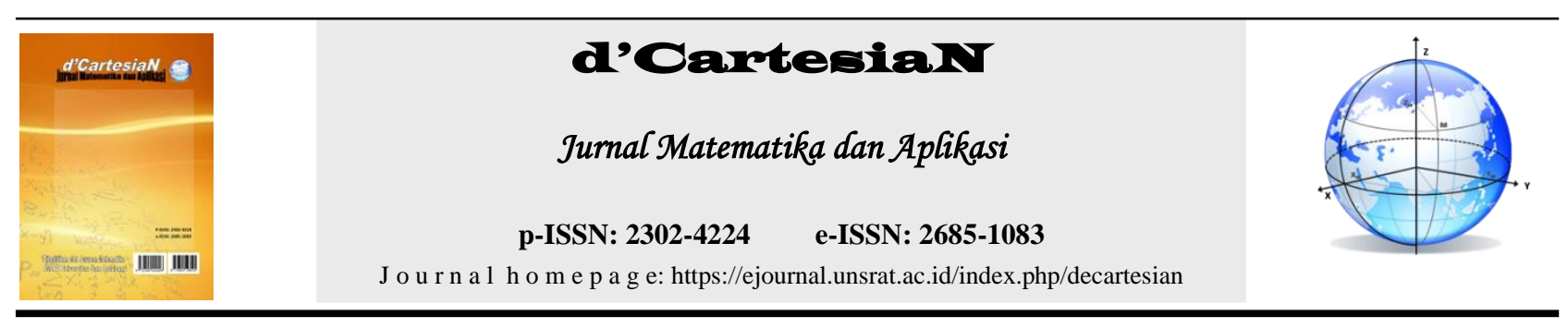

\title{
Penerapan Regresi Binomial Negatif Dalam Mengatasi Overdispersi Regresi Poisson Pada Kasus Jumlah Kematian Ibu
}

\author{
Marzena Melisa Majore', Deiby Tineke Salaki ${ }^{*}$, Jantje Denny Prang1 \\ ${ }^{1}$ Jurusan Matematika-Fakultas Matematika dan Ilmu Pengetahuan Alam-Universitas Sam Ratulangi Manado, Indonesia
}

${ }^{*}$ Corressponding author : deibyts.mat@unsrat.ac.id

\begin{abstract}
A B S T R A K
Angka kematian ibu merupakan banyaknya kematian yang terjadi selama proses kehamilan serta dalam periode 42 hari setelah berakhirnya kehamilan per 100.000 kelahiran hidup. Hubungan antara faktor-faktor dengan banyaknya kematian ibu dapat diketahui dengan menggunakan analisis regresi Poisson. Penelitian ini menggunakan data tahun 2018 dari Dinas Kesehatan Provinsi Sulawesi Utara berupa jumlah kematian ibu sebagai variabel respon dan sejumlah variabel prediktor dengan unit pengamatannya adalah kabupaten/kota. Dalam analisis regresi Poisson, variabel respon mengasumsikan ekuidispersi (nilai ragam sama dengan nilai rataannya). Namun, dalam data riil seringkali terjadi overdispersi (nilai varians lebih besar dari mean). Salah satu cara untuk mengatasinya adalah dengan analisis regresi binomial negatif. Tujuan dari penelitian ini adalah menentukan model regresi Poisson dan regresi binomial negatif untuk mendapatkan faktor-faktor yang secara signifikan mempengaruhi jumlah kematian ibu di Provinsi Sulawesi Utara. Model regresi binomial negatif yang diperoleh adalah

$$
\hat{y}=\exp \left(0.17556+0.29437 x_{1}+0.32063 x_{4}\right)
$$

bertambahnya jumlah kasus perdarahan pada ibu hamil $\left(\boldsymbol{x}_{1}\right)$ dan jumlah kasus yang disebabkan oleh faktor-faktor lainnya $\left(\boldsymbol{x}_{4}\right)$, maka akan meningkatkan angka kematian ibu di Provinsi Sulawesi Utara.
\end{abstract}

\section{INFO ARTIKEL :}

Diterima : 12 Juli 2020

Diterima setelah revisi : 29 Agustus 2020

Tersedia online : 5 Januari 2021

\section{Kata Kunci:}

Generalized Linier Model

Multikolinearitas

Overdispersi

Sulawesi Utara

ibu hamil.

\begin{abstract}
A B S T R A C T
The maternal mortality rate is the number of deaths occurring during the pregnancy and in the period 42 days after the end of pregnancy per 100,000 live births. The relationship between factors with many maternal deaths can be noted using Poisson regression analyses. This research used the 2018 data from the provincial health office of North Sulawesi as the number of maternal deaths as a response variable and a number of predictor variables with its observation unit is district/municipality. In Poisson's regression analysis, the response variable assumes equidispersion (the value of the range equals its rating). However, in real data often occurs overdispersion (the range is greater than the value of its rating). One way to solve this is with the analysis of negative binomial regression. The purpose of this study was to apply a negative binomial regression model to Poisson regression models from the total deaths of mothers experiencing overdispersion. The use of Poisson regression model on the number of maternal deaths in North Sulawesi province does not indicate a strong indication of overdispersion. Results of the analysis showed that Poisson's regression was better than negative binomial regression in modeled the number of maternal deaths in North Sulawesi in 2018 with the following equation:$$
\hat{\mu}=\exp \left(0.4713 x_{1}\right)
$$

One case increase in number of bleeding in pregnant women $\left(\boldsymbol{x}_{1}\right)$ has a multiplicative impact of $\exp (0.4713)=0.16$ on expectation value of the number of maternal deaths..
\end{abstract}

\section{ARTICLE INFO:}

Received : 12 July 2020

Received after revision : 29 August 2020

Available online : 5 January 2021

\section{Keywords:}

Generalized Linier Model

Multicollinearity

Overdispersion

North Sulawesi

Pregnant woman.

\section{PENDAHULUAN}

Angka kematian (mortalitas) merupakan angka yang menunjukkan banyaknya kematian dari tiap seribu penduduk dalam waktu satu tahun yang disebabkan oleh suatu keadaan, berupa penyakit ataupun sebab lainnya. Peristiwa kematian di suatu wilayah dari waktu ke waktu dapat memberikan gambaran perkembangan derajat kesehatan masyarakat, yang sering digunakan sebagai indikator dalam penilaian keberhasilan program pembangunan dan pelayanan kesehatan. Kasus kematian ibu Provinsi Sulawesi Utara tahun 2016 mengalami penurunan dibandingkan dengan tahun 2015, dimana pada tahun 2016 terdapat 54 kasus menurun dibandingkan dengan tahun 2015 sebanyak 71 kasus kematian [1].

Jumlah kematian ibu dapat ditekan jika faktorfaktor yang mempengaruhinya diketahui. Hubungan 
antara faktor-faktor tersebut dengan jumlah kematian ibu dapat diketahui dengan menggunakan analisis regresi. Analisis regresi merupakan suatu metode yang digunakan untuk memprediksi nilai satu variabel berdasarkan nilai variabel yang lain. Analisis regresi dibedakan atas analisis regresi linear dan analisis regresi nonlinear. Untuk memodelkan data dalam analisis regresi nonlinear dapat menggunakan Generalized Linear Model (GLM). Salah satu analisis regresi nonlinier yang dimodelkan dengan GLM adalah analisis regresi Poisson.

Analisis regresi Poisson adalah suatu model yang digunakan untuk menganalisis hubungan antara variabel respon yang berdistribusi Poisson dengan sejumlah variabel prediktor. Regresi Poisson mengasumsikan ekuidispersi yaitu nilai ragam dari variabel repon sama dengan rataannya. Namun, pada prakteknya asumsi ini sangat jarang terjadi karena biasanya data count memiliki ragam lebih besar dari rataannya atau disebut kondisi overdispersi [2].

Overdispersi menyebabkan nilai devians model menjadi sangat besar dan menyebabkan model regresi Poisson yang dihasilkan menjadi kurang tepat. Alternatif model yang biasanya digunakan untuk mengatasi overdispersi adalah regresi binomial negatif.

\section{TINJAUAN PUSTAKA}

\subsection{Angka Kematian Ibu (AKI)}

Menurut [3] angka kematian ibu (AKI) adalah banyaknya kematian perempuan pada saat hamil atau selama 42 hari sejak terminasi kehamilan tanpa memandang lama dan tempat persalinan, yang disebabkan karena kehamilannya atau pengelolaannya, dan bukan karena sebab-sebab lain, per 100.00o kelahiran hidup. Kematian ibu yang dimaksud adalah kematian perempuan pada saat hamil atau kematian dalam kurun waktu 42 hari sejak terminasi kehamilan tanpa memandang lamanya kehamilan atau tempat persalinan, yakni kematian yang disebabkan karena kehamilannya atau pengelolaannya, tetapi bukan karena sebab-sebab lain seperti kecelakaan, terjatuh dan lainlain.

\subsection{Distribusi Keluarga Eksponensial}

Menurut [4] suatu variabel acak Y yang menyebar keluarga eksponensial dengan parameter $\theta$, memiliki distribusi peluang yang dapat ditulis dalam bentuk:

$$
f(y ; \theta)=s(y) t(\theta) e^{\wedge}(a(y) b(\theta))
$$

Dengan a,b,s dan $t$ adalah fungsi yang diketahui. Persamaan (1) dapat juga dituliskan dalam bentuk lain untuk lebih menjelaskan hubungan simetri antara y dan $\theta$ sebagai berikut:

$$
f(y ; \theta)=\exp [a(y) b(\theta)+c(\theta)+d(y)](2)
$$

Dengan $s(y)=\exp d(y)$ dan $t(\theta)=\exp c(\theta)$. Jika $a(y)=y$ maka distribusi tersebut dikatakan dalam bentuk standar dan $b(\theta)$ disebut parameter natural dari distribusi. Beberapa distribusi yang diketahui termasuk dalam keluarga eksponensial antara lain: Poisson, normal, eksponensial dan binomial negatif.

\subsection{Generalized Linear Model (GLM)}

GLM merupakan perluasan dari model linier klasik dimana $Y$ berdistribusi secara keluarga eksponensial [2]. Model GLM dapat dituliskan sebagai berikut :

$$
g\left(\mu_{i}\right)=\boldsymbol{x}_{i}^{T} \boldsymbol{\beta}
$$

Berdasarkan persamaan (3), menurut [4] GLM

memiliki tiga komponen, yaitu :

1. Komponen acak yaitu peubah respon $Y_{1}, Y_{2}, \ldots, Y_{n}$ yang diasumsikan menyebar keluarga ekponensial.

2. Parameter $\boldsymbol{\beta}$ dan peubah penjelas

$$
\boldsymbol{X}=\left[\begin{array}{c}
\boldsymbol{x}_{1}^{T} \\
\vdots \\
\boldsymbol{x}_{n}^{T}
\end{array}\right]=\left[\begin{array}{ccc}
x_{11} & \ldots & x_{1 p} \\
\ldots & & \ldots \\
x_{n 1} & \ldots & x_{n p}
\end{array}\right]
$$

3. Fungsi penghubung yaitu suatu fungsi monoton $g$ yang dapat diturunkan sedemikian hingga:

$g\left(\mu_{i}\right)=\boldsymbol{x}_{i}^{T} \boldsymbol{\beta}$ dengan $\mu_{i}=E\left(Y_{i}\right)$
Dengan $\boldsymbol{x}_{i}=\left[\begin{array}{c}x_{i 1} \\ \vdots \\ x_{i p}\end{array}\right]$ sehingga $\boldsymbol{x}_{i}^{T}=\left[\begin{array}{lll}x_{i 1} & \ldots & x_{i p}\end{array}\right]$

\subsection{Distribusi Poisson}

Distribusi Poisson merupakan distribusi yang digunakan untuk peristiwa yang memiliki probabilitas kejadiannya kecil, dimana kejadian tersebut tergantung pada interval waktu tertentu atau disuatu daerah tertentu. Menurut [4] fungsi probabilitas untuk variabel acak diskrit $Y$ adalah:

$$
f(y \mid \theta)=\frac{\theta^{y} e^{-\theta}}{y !}, y=0,1,2, \ldots
$$

Dimana $y$ bernilai $0,1,2, \ldots$ dan $\theta=E(Y)$ adalah nilai ekspetasi atau nilai rataannya.

Suatu peubah acak $Y$ dikatakan menyebar keluarga eksponensial, jika fungsi kepadatan peluangnya dapat dituliskan seperti persamaan (2). Distribusi peluang Poisson pada persamaan (4) dapat ditulis dalam bentuk distribusi keluarga eksponensial sebagai berikut:

$$
\begin{aligned}
& f(y \mid \theta)=e^{-\theta} \theta^{y}(y !)^{-1} \\
& \quad=\exp (-\theta+y \log \theta-\log y !) \\
& \quad=\exp (y \log \theta-\theta-\log y !)
\end{aligned}
$$

Jadi dapat disimpulkan distribusi Poisson merupakan keluarga eksponensial dengan $a(y)=y$, $c(\theta)=-\theta$ dan $d(y)=-\log (y !)$. Parameter $b(\theta)=\log \theta$ disebut sebagai parameter naturalnya.

\subsection{Goodness Of Fit}

Menurut [5] uji kesesuaian (goodness of fit) bertujuan untuk mengambil kesimpulan tentang sebaran populasi. Uji goodness of fit digunakan untuk mengetahui suatu data berdistribusi Poisson atau tidak dengan menggunakan uji Kolmogorov-Smirnov. Hipotesis:

$H_{0}=$ Sampel berasal dari populasi yang berdistribusi Poisson

$H_{1}=$ Sampel tidak berasal dari populasi yang berdistribusi Poisson

Dengan mengambil taraf signifikansi $\alpha$ maka kriteria pengujiannya menolak $H_{0}$ jika nilai $p-$ value $<\alpha$

\subsection{Multikolinearitas}

Menurut [6] multikolinearitas adalah kondisi adanya korelasi yang tinggi antar variabel-variabel prediktor dalam model. Multikolinearitas dapat dideteksi dari nilai VIF (Varians Inflation Factor). Jika nilai VIF lebih besar dari 10 maka dikatakan terjadi multikolinearitas antar variabel prediktor. Nilai $V I F_{j}$ dinyatakan sebagai berikut:

$$
V I F_{j}=\frac{1}{1-R_{j}^{2}}
$$




\section{Penerapan Regresi Binomial Negatif Dalam Mengatasi Overdispersi Regresi Poisson Pada Kasus Jumlah Kematian Ibu}

d'Cartesian: Jurnal Matematika dan Aplikasi, Vol.9, No. 2, (September 2020): 133-139

Nilai $R_{j}^{2}$ menyatakan koefisien determinasi antara $\boldsymbol{x}_{j}$ dengan variabel prediktor lainnya.

\subsection{Maximum Likelihood Estimator (MLE)}

Menurut [4] estimasi parameter pada regresi Poisson dilakukan dengan menggunakan metode MLE. MLE merupakan salah satu metode penaksiran parameter suatu model yang distribusinya diketahui. Prinsip dari metode ini adalah mencari taksiran maksimum likelihood dari parameter, yaitu taksiran dari parameter-parameter yang memaksimumkan fungsi likelihood. Fungsi log-likelihood dapat ditulis dalam persamaan berikut:

$$
\ell(\theta)=\log L(\theta)=\sum_{i=1}^{n}\left\{y_{i} \log (\theta)-\theta-\log \left(y_{i} !\right)\right\}
$$

Pendugaan bagi parameter $\theta$ diperoleh dengan menurunkan persamaan dan menyamakan dengan 0 . Namun demikian secara analitik tidak memungkinkan atau sulit dilakukan sehingga umumnya dilakukan secara numerik dengan metode Newton-Rapson.

\subsection{Regresi Poisson}

Regresi Poisson merupakan analisis regresi nonlinier dari distribusi Poisson, dimana analisis ini sangat cocok digunakan dalam menganalisis data diskrit. Model regresi Poisson termasuk dalam GLM karena variabel respon Y memiliki sebaran dari keluarga eksponsial yaitu sebaran Poisson., tidak terdapat multikoleniaritas antar variabel prediktor dan mengasumsikan ekuidispersi, yaitu $\operatorname{Var}(Y)=E(Y)$ [7].

Dalam regresi Poisson, fungsi penghubung yang digunakan adalah fungsi log, karena rata-rata dari variabel responnya akan berbentuk fungsi eksponensial dan menjamin bahwa nilainya bernilai non-negatif. Menurut [8] regresi Poisson dapat dinyatakan sebagai berikut:

$$
\eta_{i}=\ln \left(\mu_{i}\right)=\beta_{0}+\beta_{1} x_{i 1}+\beta_{2} x_{i 2}+\cdots+\beta_{p} x_{i p}
$$

Dimana :

$$
\begin{aligned}
& \eta_{i}=\text { fungsi penghubung } \\
& \mu_{i}=\text { nilai tengah peubah respon ke- } i \\
& \beta_{0}=\text { konstanta } \\
& \begin{aligned}
\beta_{1}, \beta_{2}, \ldots, \beta_{p}= & \text { koefisien regresi variabel prediktor } \\
& \text { ke- } 1 \text { sampai } p \\
x_{i p} & \text { nilai variabel prediktor ke- } j \text { amatan } \\
& \text { ke- } i
\end{aligned}
\end{aligned}
$$

\subsection{Overdispersi}

Menurut [8] overdispersi merupakan kondisi dimana nilai $\operatorname{Var}(Y)>E(Y)$. Overdispersi dapat dideteksi dengan menentukan rasio dispersi $(\phi)$, yaitu rasio antara $\chi^{2}$ dan derajat bebasnya $(d b)$, yaitu:

$$
\phi=\frac{\chi^{2}}{d b}
$$

Dengan $d b=N-p$. Suatu model dikatakan mengalami overdispersi jika $\phi$ bernilai lebih dari satu. Untuk model regresi Poisson maka $\chi^{2}$ dituliskan sebagai

$$
\chi^{2}=\sum_{i=1}^{N} \frac{\left(y_{i}-E(Y)\right)^{2}}{\operatorname{Var}(Y)}
$$

dengan $y_{i}$ merupakan nilai pengamatan ke- $i$ dari variabel respon.

\subsection{Regresi Binomial Negatif}

Model regresi binomial negatif lebih fleksibel dibandingkan model Poisson karena rataan dan ragam dari model binomial negatif tidak harus sama. Fungsi peluang binomial negatif adalah sebagai berikut:

$$
P(y \mid \mu, \alpha)=\frac{\left(y+\alpha^{-1}\right)}{y !\left(\alpha^{-1}\right)}\left(\frac{\alpha \mu}{1+\alpha \mu}\right)^{y}\left(\frac{1}{1+\alpha \mu}\right)^{\alpha^{-1}}
$$

Dengan $\alpha$ merupaka parmeter dispersi, $\alpha>0$. Jika $\alpha \rightarrow$ 0 , maka distribusi ini mendekati Poisson $(\mu)$. sebaran Binomial Negatif memiliki rataan $E(Y)=\mu$ dan ragan $\operatorname{var}(Y)=\mu+\mu^{2} \alpha[9]$.

Menurut [8] regresi Poisson dapat dinyatakan sebagai berikut:

$$
\eta_{i}=\ln \left(\mu_{i}\right)=\beta_{0}+\beta_{1} x_{i 1}+\beta_{2} x_{i 2}+\cdots+\beta_{p} x_{i p}
$$

Dimana :

$$
\begin{aligned}
& \eta_{i} \quad=\text { fungsi penghubung } \\
& \mu_{i} \quad=\text { nilai tengah peubah respon ke- } i \\
& \beta_{0} \quad=\text { konstanta } \\
& \beta_{1}, \beta_{2}, \ldots, \beta_{p}=\text { koefisien regresi variabel prediktor } \\
& \text { ke-1 sampai } p \\
& x_{i p} \quad=\text { nilai variabel prediktor ke- } j \text { amatan } \\
& \text { ke- }-
\end{aligned}
$$

\subsection{Pengujian Model}

\subsubsection{Uji Wald}

Uji Wald dilakukan terhadap masing-masing variabel prediktor yang ada untuk mengetahui pengaruh yang diberikan setiap variabel prediktor terhadap nilai variabel respon.

Hipotesis

$H_{0}: \beta_{j}=0, j=1,2, \ldots$ (variabel prediktor tidak berpengaruh terhadap variabel respon)

$H_{1}: \beta_{j} \neq 0$ (variabel prediktor berpengaruh terhadap variabel respon)

Statistik Uji:

$$
W_{j}=\left[\frac{\hat{\beta}_{j}}{S E\left(\hat{\beta}_{j}\right)}\right]^{2}
$$

Kriteria Pengujian : Jika nilai $W>X^{2}{ }_{(\alpha, 1)}$ atau $P-$ value $<\alpha$ maka tolak $H_{0}$ artinya koefisien regresi tersebut signifikan [8].

\subsubsection{Akaike information Criteria (AIC)}

AIC merupakan informasi perbedaan yang dianggap sebagai dasar kriteria untuk mengevaluasi kebaikan model. AIC didefinisikan sebagai :

$$
A I C=-2 \ln L(\hat{\theta})+2 p
$$

dengan $L(\hat{\theta})$ adalah nilai likelihood model, dan $p$ adalah banyaknya parameter. Nilai AIC yang semakin kecil menunjukan model yang diperoleh semakin baik [10]

\subsubsection{Uji likelihood ratio (T)}

Menurut [10] uji likelihood ratio (T) biasa digunakan untuk uji perbandingan model. Berikut ini adalah hipotesis uji Likelihood ratio.

Hipotesis:

$H_{0}: k=0 \quad$ (Model regresi Poisson lebih baik daripada model regresi binomial negatif) 
$H_{1}: k \neq 0 \quad$ (Model regresi binomial negatif lebih baik daripada model regresi Poisson)

Statistik Uji:

$$
T=2\left(\hat{L}_{B N}-\hat{L}_{\text {Poisson }}\right)
$$

Dimana:

$$
\begin{array}{ll}
\hat{L}_{B N} & \begin{array}{l}
\text { : nilai log-likelihood model regresi } \\
\text { binomial negatif }
\end{array} \\
\hat{L}_{\text {Poisson }} & \begin{array}{l}
\text { : nilai log-likelihood model regresi } \\
\text { Poisson }
\end{array}
\end{array}
$$

\section{METODE PENELITIAN}

\subsection{Waktu dan Tempat Penelitian}

Data yang digunakan dalam penelitian ini adalah data sekunder yaitu data angka kematian ibu yang berasal dari Dinas Kesehatan Provinsi Sulawesi Utara. Pada penelitian ini, unit pengamatannya meliputi 15 kota dan kabupaten di Provinsi Sulawesi Utara yakni terdiri dari 4 kota dan 11 kabupaten. Data yang dimaksud termuat dalam Profil Kesehatan Sulut [1]

\subsection{Teknik Pengambilan Sampel}

Variabel penelitian yang digunakan dalam penelitian ini berupa variabel respon $(Y)$ yakni banyaknya kasus kematian ibu dan sejumlah variabel prediktor yaitu:

$\boldsymbol{x}_{1}=$ banyaknya ibu yang mengalami perdarahan

$\boldsymbol{x}_{2}=$ banyaknya ibu yang mengalami hipertensi dalam kehamilan

$\boldsymbol{x}_{3}=$ banyaknya ibu yang mengalami infeksi

$\boldsymbol{x}_{4}=$ banyaknya ibu yang mengalami sebab-sebab lainnya.

\subsection{Metode Penelitian}

Berikut ini langkah-langkah untuk menganalisis data:

1. Input data

2. Analisis Deskripsi

3. Uji goodness of fit

4. Mengidentifikasi Multikolinearitas

5. Menentukan model regresi Poisson

6. Mengidentifikasi overdispersi pada model regresi Poisson.

7. Menentukan model regresi Binomial Negatif

8. Pemilihan model terbaik

9. Menarik kesimpulan

\section{HASIL DAN PEMBAHASAN}

\subsection{Analisis Deskripsi}

Banyaknya kematian ibu dan data variabel prediktor di Provinsi Sulawesi Utara tahun 2018 yang digunakan dalam penelitian ini ditunjukkan pada Tabel 1.

Berdasarkan Gambar 2 terlihat bahwa banyaknya kematian ibu yang tertinggi terdapat di Kabupaten Minahasa Selatan, yaitu sebanyak 11 kasus. Di ibukota propinsi yaitu Kota Manado ada 10 kasus kemudian diikuti oleh Kabupten/Kota lainnya. Sebaliknya di Kabupaten Sitaro tercatat tidak ada kasus kematian ibu sepanjang tahun 2018.
Tabel 1. Data Penelitian Jumlah Kematian Ibu di Sulawesi Utara 2018

\begin{tabular}{lccccc}
\hline Kabupaten/Kota & $\boldsymbol{y}$ & $\boldsymbol{x}_{\mathbf{1}}$ & $\boldsymbol{x}_{\mathbf{2}}$ & $\boldsymbol{x}_{\mathbf{3}}$ & $\boldsymbol{x}_{\mathbf{4}}$ \\
\hline Bolmong & 6 & 0 & 1 & 0 & 5 \\
Minahasa & 3 & 3 & 0 & 0 & 0 \\
Sangihe & 2 & 0 & 1 & 0 & 1 \\
Talaud & 1 & 1 & 0 & 0 & 0 \\
Minsel & 11 & 3 & 2 & 2 & 4 \\
Minut & 3 & 3 & 0 & 0 & 0 \\
Bolmut & 2 & 0 & 1 & 0 & 1 \\
Sitaro & 0 & 0 & 0 & 0 & 0 \\
Mitra & 2 & 1 & 0 & 0 & 1 \\
Bolsel & 3 & 3 & 0 & 0 & 0 \\
Boltim & 4 & 0 & 2 & 1 & 1 \\
Manado & 10 & 1 & 2 & 1 & 6 \\
Bitung & 1 & 1 & 0 & 0 & 0 \\
Tomohon & 1 & 1 & 0 & 0 & 0 \\
Kotamobagu & 3 & 2 & 0 & 0 & 1 \\
\hline
\end{tabular}

Sumber : Dinas Kesehatan Provinsi Sulawesi Utara.

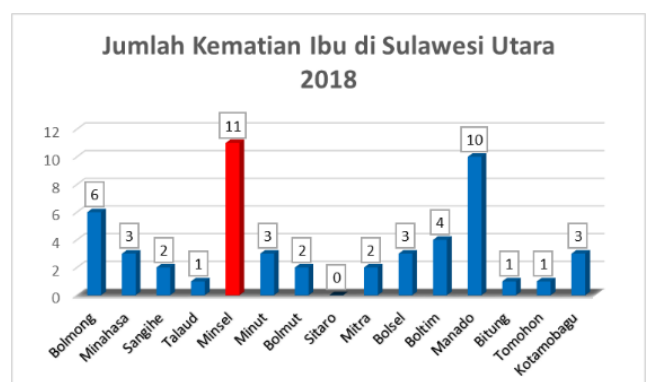

Gambar 2. Sebaran Jumlah Kematian Ibu di Sulawesi Utara tahun 2018

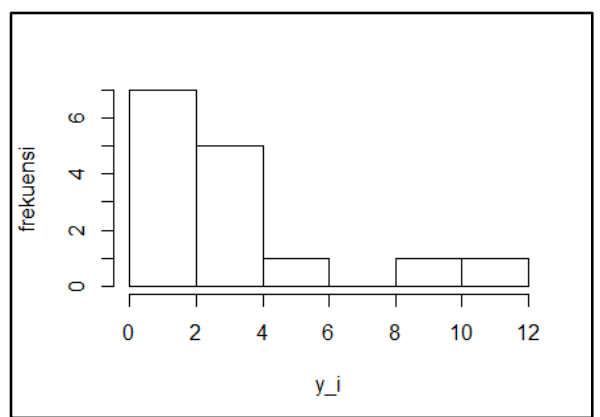

Gambar 3. Histogram Jumlah Kematian Ibu di Sulawesi Utara

Plot pada gambar 3 memperlihatkan bentuk yang tidak simetris dan cenderung mengikuti sebaran Poisson.

\subsection{Goodness Of Fit}

Uji goodness of fit untuk mengetahui suatu data berdistribusi Poisson atau tidak dengan menggunakan uji Kolmogorov-Smirnov. Dengan hipotesis:

$H_{0}=$ Data berdistribusi Poisson

$H_{1}=$ Data tidak berdistribusi Poisson

Dengan mengambil taraf signifikan $\alpha$ maka kriteria penolakan $H_{0}$ adalah jika nilai $p-$ value $<\alpha$. Hasil 


\section{Penerapan Regresi Binomial Negatif Dalam Mengatasi Overdispersi Regresi Poisson Pada Kasus \\ Jumlah Kematian Ibu}

d'Cartesian: Jurnal Matematika dan Aplikasi, Vol.9, No. 2, (September 2020): 133-139

analisis uji Kolmogorov-smirnov disajikan dalam Tabel 2.

Tabel 2. Uji Kolmogorov-Smirnov Kolmogorov-Smirnov 0,734

$$
p-\text { value }
$$$$
0,654
$$

Berdasarkan Tabel 2, dapat dilihat bahwa nilai $p$-value adalah 0,654 yang artinya lebih besar dari $\alpha=0,05$. Jadi kesimpulannya adalah terima $H_{0}$ artinya data jumlah kasus kematian ibu di Provinsi Sulawesi Utara berdistribusi Poisson.

\subsection{Multikolinearitas}

Hasil perhitungan nilai VIF masing-masing variabel prediktor terlihat pada Tabel 3 .

Tabel 3. Nilai VIF (Variance Inflation Factor)

\begin{tabular}{ccc}
\hline Variabel & & Nilai VIF \\
\hline & $x_{1}$ & 2.028512 \\
& $x_{2}$ & 7.608976 \\
& $x_{3}$ & 5.635000 \\
& $x_{4}$ & 2.240223 \\
\hline
\end{tabular}

Pada Tabel 3, terlihat bahwa nilai VIF dari semua variabel prediktor kurang dari 10. Hal ini berarti, variabel banyaknya ibu meninggal karna perdarahan, banyaknya ibu mengalami hipertensi dalam kehamilan, banyaknya ibu mengalami infeksi dan variabel banyaknya ibu yang mengalami sebab-sebab lainnya dapat digunakan untuk memodelkan jumlah kasus kematian ibu di Sulawesi Utara.

\subsection{Estimasi dan Pengujian Regresi Poisson}

Hasil estimasi untuk setiap parameter $\beta_{0}, \beta_{1}, \cdots, \beta_{4}$ disajikan dalam Tabel 4.

Tabel 4. Nilai estimasi parameter model regresi Poisson

\begin{tabular}{cccc}
\hline Parameter & Estimasi $\beta$ & Galat baku & $\operatorname{Pr}(>|\mathrm{z}|)$ \\
\hline$\beta_{0}$ & -0.2860 & 0.5332 & 0.5916 \\
$\beta_{1}$ & 0.4713 & 0.2300 & $0.0404^{*}$ \\
$\beta_{2}$ & 0.9613 & 0.6441 & 0.1356 \\
$\beta_{3}$ & -0.6860 & 0.6627 & 0.3006 \\
$\beta_{4}$ & 0.1719 & 0.1023 & 0.0928. \\
\hline
\end{tabular}

Hasil analisis pada Tabel 4 menunjukkan bahwa hanya variabel $x_{1}$ yaitu banyaknya ibu yang mengalami perdarahan yang secara signifikan mempengaruhi variabel respon. Hal ini terlihat dari nilai p-value yang bernilai kurang dari taraf nyata 0.05. Hasil estimasi parameter $\beta_{1}$ bernilai 0.4713 . Hal ini menunjukkan bahwa model regresi Poisson untuk jumlah kematian ibu di Sulawesi Utara adalah sebagaimana tercantum pada persamaan (16).

$$
\hat{\mu}=\exp \left(-0.2860+0.4713 x_{1}\right)
$$

Model regresi Poisson pada persamaan (16), menunjukkan bahwa setiap peningkatan 1 kasus ibu hamil yang mengalami perdarahan akan meningkatkan jumlah kematian ibu sebesar $\exp (0.4713)=1.16 \mathrm{kali}$ jika variabel lainnya tetap. Dengan kata lain, jika di suatu kabupaten/kota terjadi penambahan 1 kasus ibu yang mengalami perdarahan maka jumlah kematian ibu di kota/kabupaten tersebut akan meningkat sebanyak 1.16 kali dibandingkan dengan kota/kabupaten lainnya.

Uji Wald dilakukan untuk mengetahui signifikansi dari masing-masing parameter pada model regresi dengan menggunakan uji Wald sesuai dengan hasil pada Tabel 4. Berdasarkan persamaan (13), diperoleh hasil sebagaimana tertera pada Tabel 5 .

Tabel 5. Pengujian Wald

\begin{tabular}{ccc}
\hline Variabel & Nilai Wald & Keputusan \\
\hline $\boldsymbol{x}_{1}$ & 4.198936 & Tolak $H_{0}$ \\
$\boldsymbol{x}_{2}$ & 2.227467 & Terima $H_{0}$ \\
$\boldsymbol{x}_{3}$ & 1.071555 & Terima $H_{0}$ \\
$\boldsymbol{x}_{4}$ & 2.823583 & Terima $H_{0}$ \\
\hline
\end{tabular}

Keputusan penolakan hipotesisnya disajikan dalam Tabel 5. Kriteria ujinya adalah tolak $H_{0}$ jika nilai $W>X^{2}{ }_{(0.05,1)}=3.841$ sedangkan terima $H_{0}$ jika nilai $W<X^{2}{ }_{(0.05,1)}=3.841$. Nilai Wald dari peubah $\boldsymbol{x}_{2}, \boldsymbol{x}_{3}$, $\boldsymbol{x}_{4}$ kurang dari nilai tabel $\mathrm{X}_{(0.05,1)}$ artinya $H_{0}$ diterima sehingga dapat disimpulkan bahwa ketiga variabel ini tidak memiliki pengaruh secara signifikan pada $\alpha=$ 0.05. Sebaliknya nilai Wald untuk $\boldsymbol{x}_{1}$ lebih besar dari $\mathrm{X}^{2}{ }_{(0.05,1)}$ sehingga disimpulkan bahwa variabel ini memiliki pengaruh secara signifikan pada $\alpha=0.05$ berarti $H_{0}$ ditolak.

Hasil ini sejalan dengan hasil Survey Demografi dan Kependudukan Indonesia (SDKI) 2012 bahwa penyebab utama kematian ibu adalah karena perdarahan postpartum (SDKI, 2012). Hal ini dipertegas oleh Achadi (2019) bahwa urutan pertama dari 5 penyebab $75 \%$ kasus kematian ibu adalah pendarahan.

\subsection{Uji Overdispersi}

Regresi Poisson mengasumsikan equidispersi yaitu nilai rata-rata variabel respon sama dengan nilai ragamnya. Jika nilai rata-ratanya lebih besar dari nilai ragamnya maka dikatakan terjadi overdispersi. Hasil pengujian overdispersi disajikan dalam Tabel 6 .

Tabel 6. Uji Overdispersi terhadap Variabel Respon $Y$

\begin{tabular}{ccc}
\hline Rata-rata & Ragam & Dispersion \\
\hline 3.467 & 10.267 & 0.232
\end{tabular}

Berdasarkan Tabel 6, dapat diketahui bahwa dengan menggunakan persamaan (15), diperoleh nilai person dispersi sebesar 0.232. Nilai Pearson dispersi yang kurang dari satu ini mengindikasikan tidak terjadi overdispersi. Meski demikian ragamnya bernilai 10.266 yang melebihi nilai rataannya yang merupakan salah satu indikasi overdispersi. Hasil yang tidak konsisten ini memerlukan penelitian lebih lanjut. Penelitian lanjut antara lain dapat berupa penanganan data atau pengujian overdispersi dengan pendekatan lain. 


\subsection{Etimasi dan Pengujian Regresi Binomial Negatif}

Hasil pengujian overdispersi pada sub bab sebelumnya, tidak sepenuhnya mengindikasikan adanya overdispersi. Hal ini mendorong penulis untuk melakukan analisis lanjut dengan menggunakan regresi binomial negatif sebagai salah satu alternatif penanganan overdispersi. Penentuan model regresi binomial negatif dilakukan pada semua kombinasi dari 4 variabel prediktor yaitu sebanyak 15 kemungkinan model Pada Tabel 7 disajikan empat model masingmasing dengan kombinasi 1, 2, 3 dan 4 variable prediktor yang memiliki nilai AIC terkecil.

Tabel 7. Nilai AIC dari Kombinasi Model

\begin{tabular}{ccc}
\hline No & Model & AIC \\
\hline \multirow{1}{*}{1} & $\exp \left(\beta_{0}+\beta_{4} \boldsymbol{x}_{4}\right)$ & 56.133 \\
2 & $\exp \left(\beta_{0}+\beta_{1} \boldsymbol{x}_{1}+\beta_{4} \boldsymbol{x}_{4}\right)$ & 55.011 \\
& $\exp \left(\beta_{0}+\beta_{1} \boldsymbol{x}_{1}+\beta_{2} \boldsymbol{x}_{2}+\beta_{4} \boldsymbol{x}_{4}\right)$ & 55.24 \\
3 & $\exp \left(\beta_{0}+\beta_{1} \boldsymbol{x}_{1}+\beta_{2} \boldsymbol{x}_{2}+\beta_{3} \boldsymbol{x}_{3}+\beta_{4} \boldsymbol{x}_{4}\right)$ & 56.133 \\
4 & & \\
\hline
\end{tabular}

Tabel 7 menunjukkan bahwa model dengan nilai AIC terkecil adalah model 2 yaitu model regresi binomial negatif dengan variabel prediktor $\boldsymbol{x}_{1}$ dan $\boldsymbol{x}_{4}$. Hasil dugaan parameter dari regresi binomial negatif yang menggunakan variabel prediktor $x_{1}$ dan $x_{4}$, ditampilkan pada Table 8 .

Tabel 8. Estimasi Nilai $\beta$ pada Model 2 Regresi Binomial Negatif

\begin{tabular}{cccc}
\hline Parameter & Estimasi $\beta$ & Galat baku & $\operatorname{Pr}(>|\mathrm{z}|)$ \\
\hline Intercept & 0.17556 & 0.30448 & 0.5642 \\
$x_{1}$ & 0.29437 & 0.11790 & $0.0125^{*}$ \\
$x_{4}$ & 0.32063 & 0.05863 & $4.54 \mathrm{e}-08^{* * *}$ \\
\hline
\end{tabular}

Dari Tabel 8 dapat disimpulkan bahwa model yang dihasilkan adalah :

$$
\hat{\mu}=\exp \left(0.17556+0.29437 x_{1}+0.32063 x_{4}\right)
$$

Model pada persamaan (20) menunjukkan bahwa setiap penambahan satu kasus ibu hamil yang mengalami perdarahan $\left(x_{1}\right)$ akan menaikkan nilai harapan untuk kematian ibu sebesar $\exp (0.29437)=$ 1.3423 kali bila setiap variabel prediktor lainnya tetap. Dengan kata lain, penambahan satu kasus perdarahan akan meningkatkan kasus kematian ibu sebesar 1.3423 . Setiap penambahan satu kasus ibu hamil yang mengalami gangguan kesehatan akibat sebab-sebab lainnya $\left(x_{4}\right)$ akan menaikkan nilai harapan kematian ibu sebesar $\exp (0.32063)=1.377996$ kali bila setiap variabel prediktor lainnya tetap. Dengan kata lain, penambahan satu kasus untuk sebab-sebab lainnya $\left(x_{4}\right)$ akan meningkatkan kasus kematian ibu sebesar 1.377996 kali.

Uji Wald akan dilakukan pada model 2 dari Tabel 7 yang hasilnya dapat dilihat pada Tabel 9.
Tabel 9. Pengujian Wald Untuk Model Regresi Binomial Negatif

\begin{tabular}{cccc}
\hline Variabel & Wald & $\boldsymbol{X}^{\mathbf{2}}{ }_{(\mathbf{0 . 0 5} ; \mathbf{1})}$ & Keputusan \\
\hline $\boldsymbol{x}_{1}$ & 6.233895 & 3.841459 & Tolak $H_{0}$ \\
$\boldsymbol{x}_{4}$ & 29.979441 & 3.841459 & Tolak $H_{0}$ \\
\hline
\end{tabular}

Berdasarkan hasil analisis pada Tabel 9, dapat dilihat bahwa nilai Wald dari variabel $\boldsymbol{x}_{1}, \boldsymbol{x}_{4}$ lebih besar dari nilai tabel $\mathrm{X}^{2}{ }_{(0.05,1)}$ sehingga disimpulkan bahwa $H_{0}$ ditolak. Hal ini mengindikasikan bahwa kedua variabel ini memiliki pengaruh signifikan pada $\alpha=0.05$. Dengan kata lain, banyaknya ibu yang mengalami perdarahan dan banyaknya ibu yang mengalami gangguan kesehatan yang disebabkan oleh faktor-faktor lainnya memiliki pengaruh secara signifikan terhadap jumlah kematian ibu di Sulawesi Utara.

\subsection{Pemilihan Model Terbaik}

Pemilihan model regresi yang terbaik perlu dilakukan untuk memperoleh hasil analisis regresi yang optimal. Kriteria yang dapat membantu untuk memilih model terbaik adalah Akaike information Criteria (AIC) dan nilai uji Likelihood Ratio (T). Kriteria ini dimaksudkan untuk menentukan tingkat kebaikan model dari regresi binomial negatif dibandingkan dengan regresi Poisson berdasarkan nilai AIC sebagaimana disajikan dalam Tabel 10.

Tabel 10. Nilai AIC Model Regresi Poisson dan Binomial Negatif Terpilih

\begin{tabular}{cc}
\hline Model & Nilai AIC \\
\hline Regresi Poisson & 54.132 \\
Regresi Binomial Negatif Terpilih & 55.011 \\
\hline
\end{tabular}

Tabel 10 menunjukkan AIC dari model regresi Poisson lebih kecil dari pada AIC model regresi binomial negatif. Hal ini menunjukkan bahwa model regresi Poisson lebih baik dalam menentukan faktor-faktor yang mempengaruhi jumlah kematian ibu di Sulawesi Utara.

Pemilihan model terbaik juga dilakukan dengan uji likelihood ratio (T). Berikut ini adalah hipotesis uji Likelihood ratio.

Hipotesis:

$H_{0}: k=0$ (Model regresi Poisson lebih baik daripada model regresi binomial negatif) $H_{1}: k \neq 0$ (Model regresi binomial negatif lebih baik daripada model regresi Poisson)

Dengan kriteria pengujian tolak $H_{0}$ jika $T>X^{2}{ }_{(0,05 ; 1)}$. Berdasarkan persamaan (15), maka diperoleh:

$$
T=2(-23.50527+22.06613)=-2.87828
$$

Untuk nilai $X^{2}{ }_{(0,05 ; 1)}=3.841459$. Maka hasil yang diperoleh adalah nilai $T<X^{2}{ }_{(0,05 ; 1)}$ yang menunjukkan penerimaan $H_{0}$, berarti model regresi Poisson lebih baik daripada model regresi binomial negatif.

\section{Penutup}

\subsection{Kesimpulan}

Penggunaan model regresi Poisson pada angka kematian ibu di Provinsi Sulawesi Utara tidak 


\section{Penerapan Regresi Binomial Negatif Dalam Mengatasi Overdispersi Regresi Poisson Pada Kasus Jumlah Kematian Ibu}

d'Cartesian: Jurnal Matematika dan Aplikasi, Vol.9, No. 2, (September 2020): 133-139

menujukkan indikasi kuat adanya overdispersi. Hasil analisis menunjukkan bahwa regresi Poisson lebih baik dari pada regresi binomial negatif dalam memodelkan jumlah kematian ibu di Sulawesi Utara tahun 2018 dengan persamaan sebagai berikut:

$$
\hat{\mu}=\exp \left(0.4713 x_{1}\right)
$$

Dimana jika terjadi penambahan satu kasus perdarahan akibat melahirkan maka akan meningkatkan nilai rataan jumlah kasus kematian ibu sebesar 1.16 kali.

\subsection{Saran}

1. Pemerintah dan Dinas Kesehatan harus lebih memperhatikan mutu kerja dari tenaga kesehatan untuk mencegah terhadap kemungkinan terjadinya kasus perdarahan akibat melahirkan serta dalam menangani/mengatasi faktor-faktor lainnya pada ibu hamil saat melahirkan.

2. Penelitian selanjutnya dapat dilakukan dengan mengkaji penyebab overdispersi dan menggunakan metode GLM lainnya untuk mengatasi overdispersi.

\section{REFERENSI}

[1] Dinas Kesehatan Provinsi Sulawesi Utara. 2016. Profil Kesehatan Provinsi Sulawesi Utara Tahun 2016. Manado

[2] McCullagh, P dan Nelder, JA. 1989. Generalized Linear Models: 2nd Edition. London: Chapman and Hall.

[3] Budi Utomo. 1985. Mortalitas: Pengertian dan Contoh Kasus di Indonesia. Jakarta: Fakultas Kesehatan Masyarakat, UI.

[4] Dobson. Annette, J. 2002. An Introduction to Generalized Linear Models. Chapman and Hall, London.

[5] Lungan, R. 2006. Aplikasi Statistika dan Hitung Peluang. Yogyakarta: Graha Ilmu

[6] Hocking, R. R. 1996. Methods and Applications of Linears Models, Second Edition. New York: John Wiley and Sons, Inc.

[7] Hardin, J. W., Hilbe, J. M. 2007. Generalized Linear Models and Extensions. Texas: A Stata Press Publication.

[8] Agresti, A. 2007. Categorical Data Analysis. Second Edition. New York : John Wiley and Sons, Inc

[9] Ismail N \& Jemain A.A. 2007. Handling Overdispersion with Binomial Negatif and Generalized Poisson Regression Models. . Casualty Actuarial Society Forum : 103-158.

[10] Joseph, M.H. 2011. Negative Binomial Regression. Second Edition. Cambridge University Press, New York.

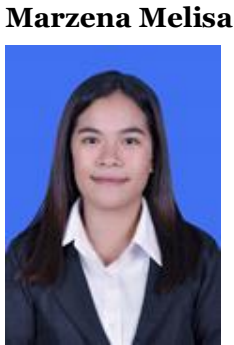

Majore (mjrmelisa@gmail.com)

Lahir di Essang, pada tanggal 10 Maret 1998. Menempuh pendidikan tinggi Jurusan Matematika, FMIPA, Universitas Sam Ratulangi Manado. Tahun 2020 adalah tahun terakhir ia menempuh studi. Makalah ini merupakan hasil penelitian skripsinya yang dipublikasikan.

Deiby Tineke Salaki (deibyts.mat@unsrat.ac.id)

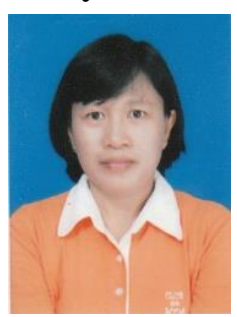
Lahir di Minahasa Selatan tanggal 17 Desember 1972. Gelar sarjana Matematika diperoleh tahun 1998 di Jurusan Matematika IPB Bogor. Tahun 2009 menyelesaikan studi S2, di Jurusan Matematika IPB Bogor. Tahun 2018 menyelesaikan studi S3 pada bidang Matematika di IPB Bogor. Saat ini menjadi pengajar tetap di Jurusan Matematika F-MIPA Unsrat Manado.

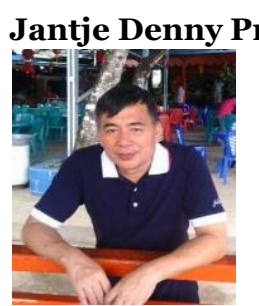

ang (jantjeprang@gmail.com)

Lahir pada tanggal 20 Desember 1985. Gelar Master Sains (M.Si) diperoleh dari Institut Pertanian Bogor. Ia bekerja di UNSRAT di Program Studi Matematika sebagai pengajar akademik tetap UNSRAT. 